May 2012

\title{
Certification of Librarians: An Unproven Demand
}

Jonathan Pacheco Bell

San Jose State University, School of Library and Information Science, jbell213@gmail.com

Follow this and additional works at: https://scholarworks.sjsu.edu/ischoolsrj

Part of the Library and Information Science Commons

\section{Recommended Citation}

Bell, J. P. (2012). Certification of Librarians: An Unproven Demand. School of Information Student Research Journal, 2(1). https://doi.org/10.31979/2575-2499.020103 Retrieved from https://scholarworks.sjsu.edu/ischoolsrj/vol2/iss1/3

This article is brought to you by the open access Journals at SJSU ScholarWorks. It has been accepted for inclusion in School of Information Student Research Journal by an authorized administrator of SJSU ScholarWorks. For more information, please contact scholarworks@sjsu.edu. 


\title{
Certification of Librarians: An Unproven Demand
}

\author{
Abstract \\ This paper examines whether certification of librarians is necessary to ensure high quality service. The \\ paper explains the purpose of professional certification and provides a synopsis of the history of national \\ librarian certification initiatives in the U.S. A literature review evaluates arguments supporting and \\ opposing certification. Arguments in favor of certification are unconvincing and reveal certification \\ supporters' professional insecurities, failure to consider the certification bureaucracy that would be \\ created, and lack of evidence to support their claims. Given these findings, the paper concludes that \\ librarian certification is unnecessary. Library professionals are encouraged to take other proactive steps \\ to expand their role, importance, and impact in the $21^{\text {st }}$ century.

\section{Keywords} \\ librarian, certification, licensure, professionalization, competency \\ About Author \\ Jonathan Pacheco Bell is an MLIS student at SJSU-SLIS and a Research Assistant for SJSU's IMLS grant- \\ funded national study "Making Space for Young Adults in Public Libraries: Establishing a Research \\ Foundation." Jonathan received his M.A. in Urban Planning from UCLA and studied political science and \\ architecture as an undergraduate. He works as an urban planner in Los Angeles, CA.
}




\section{Certification of Librarians: An Unproven Demand}

Certification of librarians has been a matter of heated debate in the library and information science (LIS) profession for over a century. Supporters contend certification is needed to "protect the profession from further decline, and show the world that professional librarians are the only ones who can provide a high level of research and guidance" (Carson, 1997, p. 15). Opponents counter that certification is distracting and unnecessary-librarians are admonished to "get over it" (Nussbaumer, 2005, p. 139). Both sides offer impassioned stances but "no consensus" on the matter (Lindberg, 1990, p. 157). The continuing impasse on librarian certification forms the basis of this paper. In light of the increasing complexity and evolving role of librarianship in the $21^{\text {st }}$ century, proper librarian training and qualifications are paramount concerns to practitioners and the public alike. Accordingly, this paper examines the following research question: Is certification of librarians necessary to ensure high quality service? Upon reviewing both sides of the debate, the arguments advocating national librarian certification are unconvincing. Supporters of certification appear insecure about the librarian's evolving role, fail to consider the expansive bureaucracy certification would create, and, in the end, offer no compelling evidence to require certification.

\section{Accreditation, Licensure, and Certification}

The LIS profession uses accreditation, licensure, and certification as means to ensure quality control over library schools and practitioners. These are related but distinct terms that require clarification. Goggin (1993) cogently defined these terms as they are used within the LIS field. "Accreditation is the process of examining the educational programs that prepare persons for entrance into the profession and attesting that the programs meet certain predetermined and predescribed standards" (pp. 186-187). In other words, accreditation confirms the competency of library schools, not librarians. The Office of Accreditation of the American Library Association (ALA) accredits library schools in the United States and Canada (American Library Association, 2012).

Licensure and certification, on the other hand, operate at the individual practitioner level. "Licensure is the legal requirement that each person wishing to practice in a profession must obtain a license [which] gives the person the right to perform the duties of that profession" (Goggin, 1993, p. 187). As legal entitlements, licenses are issued and regulated by governmental agencies. Though closely related, licensure and certification are not synonymous, a fact often lost in the debate leading to confusion over the terms (Kaatrude, 1992). Within the LIS field, licensure requirements are generally limited to public school librarians who 
also hold teacher credentials. As Stripling (2005) pointed out, "Although... these requirements are called certificates, all of them fit within the definition of licensure because they are government-imposed requirements for entering the field of librarianship" (p. 152, emphasis in original).

In contrast, "Certification is the process by which a professional organization... recognizes a person who has successfully completed certain prescribed requirements of education and experience and has demonstrated certain skills and competencies, and declares that person qualified to practice that profession" (Goggin, 1993, p. 187). In contrast to licensure, certification programs are administered by, and solely within the purview of, professional associations and nongovernmental organizations (Willet, 1984, p. 17). These are nuanced but important distinctions. Whereas licensure is needed to protect "the health and welfare of the public" (Goggin, 1993, p. 187), certification typically is a voluntary process undertaken to establish one's professional mettle. Certified practitioners are considered qualified to practice by demonstrating mastery of their profession's core knowledge, skills, and abilities. As Grady (2009) observed, "Certification... is a well-established practice in many professions; indeed a right of passage in some fields for those who wish to progress" (p. 230).

\section{Importance of Professional Certification}

In the broadest sense, "The purpose of certification, and the setting up of educational standards in support of certification, is to raise the quality and character of professional service to the highest possible level and to maintain the quality at that level" (Equating Professional Library Qualifications, 1960, p. 29). Seemingly a modern invention, the concept of professional certification was actually developed centuries ago. According to Jordan (1948):

[T] he underlying idea [behind] certification is not new - it is almost as old as civilization. By the Middle Ages it was part and parcel of the social fabric. Not only were standards for groups definitely established in this period, but the two methods of achieving regulation of personnel that are currently used were instigated then. [Craft] guilds... established standards of training [and] controlled entrance to the trade. [Academic] groups... organized as professions with their standards established for the most part through educational institutions. (p. 100)

As societies evolved and gave rise to new professions, there has been no shortage of certification initiatives created to address the "fitness for service" question. Nearly 20 years ago, Goggin (1993) identified over 425 certification programs offered through various professional associations (p. 187). That number 
has risen exponentially given the growth of professions and industries since then. From financial planners (Certified Financial Planner, 2012) to urban planners (American Planning Association, 2012); from protection-and-security providers (American Society for Industrial Security, 2012) ${ }^{1}$ to information technology security specialists (International Information Systems Security Certification Consortium, 2012), ${ }^{2}$ the earned status of "certified professional" would seem to be the new benchmark of quality assurance. The importance of certification among professions, then, is pervasive and undeniable.

The LIS profession shows an earnest interest in assuring high quality service by way of credentialing and lifelong learning initiatives. The ALA identifies "continuing education" as one of the Core Competencies of Librarianship (American Library Association, 2009). Within the broader LIS community, an abundance of specialized continuing education programs speaks to the popularity of, and apparent desire for, post-graduate certification. For example, there are certification programs for medical librarians (Medical Library Association, 2012; Jordan, 1948), school librarians (Jesseman, Page, \& Underwood, 2011; Gerhardt, 1978), archivists (Academy of Certified Archivists, 2012), and records managers (Institute of Certified Records Managers, 2012; Phillips, 2004). Ojala (2003) even proposed "certifying a particular skill set," (p. 5) such as subject expertise or database searching.

Recently the ALA inaugurated two long-awaited certification programs: in 2006, the Certified Public Library Administrator program for library managers; and, in 2010, the Library Support Staff Certification program for paraprofessional personnel. Both programs are administered by the ALA's newly created Allied Professional Association. "The goal of the Certified Public Library Administrator (CPLA) program is to improve the quality of library service through the provision of practical knowledge and skills essential to successful library management" (Grady, 2005). Similarly, the Library Support Staff Certification (LSSC) program "allows library support staff to demonstrate their competencies and be certified by the American Library Association" (American Library Association-Allied Professional Association, 2012). CPLA and LSSC participants complete courses and submit portfolios demonstrating skills mastery. These programs are designed to improve service delivery and reinforce competencies. Library managers develop leadership abilities and fill knowledge gaps via CPLA certification. For paraprofessional staffers, LSSC certification buttresses on-the-job learning. Remarking on the value of these initiatives in relation to competency assurance, Tom Wilding (in Moran, 2003) said:

\footnotetext{
${ }^{1}$ ASIS offers three certification programs for industrial security specialists.

${ }^{2}$ ISC2 offers four certification programs for IT security specialists.
} 
In today's very complex information world, it is truer than ever before that we need to be in a continuous learning mode in order to be successful... The ALA/APA provides yet another avenue, and an important one, to document continued learning and competency development in specific areas of specialization that can enhance the portfolio of information professionals. As such, certification is important to the individual as a mark of one's continued growth and development. (p. 4)

Specifically for librarians, certification enjoys widespread support across interest groups within the LIS field. This is largely because post-graduate certification would accomplish several objectives for librarianship. As Watkins (1998) reported:

The impetus to certify seems to come from a combination of forces: a desire for more uniform standards statewide; accountability issues relative to direct state aid to libraries; increasing or improving the view of librarianship as a profession; continuing education to keep the profession current; supplemental education in areas not addressed by preservice education; and an end-goal of improving service to the public. (p. 11)

Furthermore, librarianship is evolving and becoming more complex in the $21^{\text {st }}$ century. The Information Age presents new challenges for librarians. Certification is seen as a cost-effective way to update librarians' knowledge, skills, and abilities for today's digital-centric world.

Yet, in spite of all this, no national librarian certification program exists. Rank-and-file librarians serving in our public libraries nationwide-those who interact most intimately with the public, those who largely represent the profession-have no quality assurance requirement beyond the MLIS degree. This fact is ironic given the persistent calls for librarian certification to date. This is not to say national certification has not been attempted, however. The next section reviews efforts to establish national librarian certification in the U.S. The synopsis provides historical context to the longstanding debate over whether certification is necessary to ensure high quality service.

\section{National Librarian Certification Initiatives}

The birth of modern U.S. librarianship can be traced to Melvil Dewey's professionalization initiatives in the mid-1800s (Gustaitis, 1986). The salient event was the Philadelphia Centennial Exposition of 1876, where Dewey and other library luminaries convened to deliberate the future of librarianship. By conference end, they had established the ALA, founded the Library Journal, and 
mapped out formal education requirements for librarians (Bontenbal, 2010). These were pivotal events in the library field's professionalization. Founding a national association was a particularly significant achievement. Creating the ALA "substantially increas[ed] professional identity... and establish[ed] standards of service and conduct" (Rubin, 2010, p. 80). Indeed these two objectives — establishment of service standards and professional identity-would be sought through future certification efforts.

A 1906 edition of the Library Journal features one of the earliest articles on librarian certification (Kraemer, 1948, p. 158). Three years later, California became the first state to require certification of county library directors (Goggin, 1993; Kraemer, 1948). "In enacting [California's] county free library law of 1909, the paramount importance of securing a high degree of fitness in the heads of county library systems" was achieved (Williamson, 1923, p. 126). Several states followed suit and began adopting certification requirements for publicsector librarians. ${ }^{3}$

Support for certification steadily grew within ALA ranks. By 1916, the ALA had established the Committee on Standardization of Libraries and Certification of Librarians to study the efficacy of national certification (Tai, 1925). Certification would be the subject of Professor Charles C. Williamson's keynote speech at the 1919 ALA conference in Asbury Park, New Jersey. This meeting showcased the first public address by Professor Williamson on the issue of librarian certification - an issue he would expand upon in his seminal work Training for Library Service. The foundations of that groundbreaking report lie in Williamson's presentation at Asbury Park of the paper "Some Present-Day Aspects of Library Training," in which he called for creating an ALA training board to regulate professional standards through certification (Berelson, 1949). His proposal built upon Dewey's early dogged professionalization efforts and drew inspiration from other professions, namely law and medicine, which required competency demonstration beyond the academic degree. As Kraemer (1948) observed, "His plea was for country-wide certification to give the librarians a definite professional objective, to insure a reasonable degree of competency, and to raise standards as quickly as conditions would permit" ( $p$. 158). On the surface, these improvements appeared entirely benevolent. But in proposing these objectives Williamson was also attempting to increase selectivity in librarianship. Recounting the impact of the Asbury Park keynote address, White (1976) observed:

\footnotetext{
${ }^{3}$ By 1947, thirty-two states had enacted some type of certification requirement for librarians serving in public libraries (Kraemer, 1948, p. 160). By 1993, Goggin (1993) reported that public librarian certification requirements were in place "in about half of the states" (p. 187). More recently, Grady (2009) identified eighteen states with some form of certification requirements for librarians in public libraries (p. 243).
} 
Williamson used the occasion to propose new machinery to control access to library work. Adequate control would require organization of all training activities into a single, orderly system under the general direction of an ALA Training Board... [T] he Board would be empowered to work out and adopt a scheme of standards of fitness for all grades of library service and to grant appropriate certificates to properly qualified persons. (p. 175)

Library service education had become a popular discussion topic in the aftermath of the Asbury Park conference. Williamson's controversial speech earned him regard as the foremost critic of librarian training. In 1920, he was appointed chairman of the ALA Committee on National Certification and Library Training, where he continued to advance a national certification agenda (Kramer, 1948; Tai, 1925). Debate over "proper" librarian training during that time was exacerbated by the fact that two separate pathways into librarianship existed. One path was through library schools within universities. Another was through practical training in vocational schools. Library schools for years had lobbied the ALA to "endorse them as the only appropriate forum for library training," but to no avail (Rubin, 2010, p. 84). This reluctance was largely due to sentiment in the ALA at that time considering vocational certification adequate training. In a speech at an ALA convention in 1920, Williamson even openly questioned the preeminence of library school education, saying:

There is evidently a strong feeling on the part of many members of our Library Associations... that the label of the library school gives to the individual who wears it too great an advantage over his untrained colleagues, an advantage which neither his ability nor the character of his work justifies. (Library Journal, 1921, p. 856)

The Library Journal (1921) went on to say that the certification program being developed by Williamson's ALA committee is “designed to give full professional recognition to capable and successful workers who lack library school training or formal training of any kind" (p. 856).

Bitter relations between the ALA and library schools caught the attention of the Carnegie Corporation, Andrew Carnegie's philanthropic organization and a longtime supporter and developer of public libraries. Concerned about the emerging crisis in librarian education, the Carnegie Corporation in 1921 commissioned Williamson to study U.S. library schools and to report on the findings. Published as Training for Library Service, the work is more famously known as the Williamson Report. Its impact on modern librarianship is wideranging and irrefutable. In many ways, it rescued librarian education from 
irrelevancy and possible extinction. The Williamson Report has been described as a "bold, penetrating analysis that defined the professional field, described the serious limitations within it, pointed out the possibilities of improvement... and in a very real sense, charted the possible course for a sound development within the field" (Berelson, 1949, p. 48). Of particular interest here is the Williamson Report's recommendation to establish a National Certification Board (NCB) to oversee library schools and promote professional standards via certification. In the years following his Asbury Park speech, Williamson apparently changed his position privileging vocational certification over formal education. The Williamson Report declared that proper librarian education should be housed within university library schools, followed by voluntary certification through the NCB (Williamson, 1923). In essence, the NCB was envisioned to: 1) establish "generally recognized standards and uniform methods" of service, 2) apply these standards to all practicing librarians regardless of rank or organization type, 3) align librarianship with other professions, thus improving the status of librarians in the public eye, and 4) serve as the centralized "authoritative body" to accredit library schools (Williamson, 1923, pp. 144-145).

The Williamson Report had exposed the poor quality of practicing librarians and library educators at the time. Remarking on these deficiencies, White (1976) noted that "standards of fitness were sorely at odds with professional pretensions. Librarians sought public recognition as intellectual and educational leaders" even though many had not attended college (p. 172). Thus, post-graduate certification was envisioned as a means of achieving high quality service standards among librarians nationwide.

Ironically, the library profession would adopt with enthusiasm all of the recommendations of the Williamson Report except for national certification (Rubin, 2010, p. 85). In the years after the Williamson Report's release, the ALA had attained legitimacy inside and outside the profession as the preeminent national library association. Capitalizing on this opportunity, U.S. library leaders opted to regulate library schools through a centralized ALA accreditation agency, in lieu of a separate, untested certification board (Carroll, 1970, pp. 44-45; Willet, 1984, p. 14). This arrangement was both convenient and tactical. The ALA accreditation board would have instant legitimacy, but also answered the persistent "competency assurance" questions by controlling the selection criteria and qualifications of incoming library school students (White, 1976, pp. 180-181).

Despite Williamson's inability to persuade library leaders to enact the $\mathrm{NCB}$, certification continued to be a topic of recurring debate in the decades following the Williamson Report. For example, between 1934-1949, several ALA committees and state-level library boards considered establishing state and national certification requirements for public librarians (Kavanaugh \& Wescott, 1951, pp. 199-200; Kraemer, 1948, p. 159). By 1947, thirty-two states had 
enacted some type of certification requirement for librarians serving in the public sector, although these standards applied mainly to directors of municipal and county libraries (Kraemer, 1948, p. 160). Calls for certification would continue with varying degrees of fervor in the post-World War II era. It was not until the nascent days of the Information Age that the library profession would experience a surge of interest in certification. In 1980, the National Librarians Association (NLA) released its "Position Statement on Certification of the Professional in Library and Information Science." Echoing the Williamson Report, the NLA recommended establishing a National Board of Certification for Librarians, with the familiar goals of promoting competency, continuing education, and professionalism (Kaatrude, 1992, pp. 155-156). However, the NLA proposal never gained widespread support. Since then, the closest the LIS field has come to achieving national certification has been the creation of the CPLA and LSSC voluntary certification programs.

This brief historical survey illustrates how, despite the steadfast demands of certification supporters, national librarian certification has failed to materialize as an accepted benchmark of high quality service. A focused analysis of the arguments supporting and opposing librarian certification is undertaken in the literature review below.

\section{Literature Review_Arguments "For" and "Against" Librarian Certification}

The LIS field has never reached consensus over whether certification of librarians is necessary to ensure high quality service. A review of the arguments on both sides of the debate helps to explain the continuing impasse. Part one of this literature review examines the arguments supporting certification. Part two examines opposing arguments. The ensuing section offers an analysis of the findings and a critical position on the certification debate.

\section{Arguments Favoring Certification}

Supporters of librarian certification contend that certification will: 1) ensure competency; 2) remedy MLIS deficiencies; 3) align librarianship with other professions; and 4) improve professional status.

Competency assurance. Certification is frequently justified in the interest of competency assurance (Burr, 1977; Carson, 1997; Lindberg, 1990; Williamson, 1923). The literature shows a fervent and long-held desire by certification advocates to admit only "qualified" individuals into library service. Such sentiment is largely a reaction to the profession's early protocols allowing people to practice and teach librarianship without possessing formal library education 
(Jordan, 1948; Williamson, 1923). This is precisely what drove Williamson (1923) to envisage his "proposed system of national certification [to] prevent the wholly unfit from masquerading under false pretenses" (p. 118). That same objective is at the heart of contemporary certification campaigns.

By instituting evaluative processes-exams, interviews, and portfolios-to assess one's grasp of library service competencies, certification is envisioned as a way to keep librarians up-to-date with new methods, trends, and procedures. Proponents insist that certification will mutually benefit librarians and information seekers. According to Burr (1977), certification "show[s] evidence of superior competence and skill which is important to the professional as well as to those utilizing his services" (p. 1729). Librarians deemed competent are regarded as more accountable for their services and possessing better knowledge of professional ethics (Goggin, 1993, p. 189; Thomas, Hinckley, \& Eisenbach, 1981, p. 183). While nearly all supporters call for certification through professional associations like the ALA, a few supporters have said government licensure would be a better tool to ensure competency (Carson, 1997; Conant, 1980, p. 196). As Crowley (2008) bluntly put it, "In nations where barbers, hairstylists, and cosmetologists have joined attorneys and physicians in securing state... licensing, the question naturally arises why many librarians have not done the same" (p. 123).

Closely tied to the competency assurance argument is the concern that a librarian's knowledge, skills, and abilities can become outdated due to rapid technological change (Griffiths \& King, 1986, pp. 255-256; Ingalls \& Sivak, 2005). If this became the norm, dire consequences are predicted. "[R]apidly expanding, varying resources and services in the digital age also mean expanding mistakes and uneven, often poor service standards" (Brumley, 2007, p. 46). Outdated competencies could lead to the rather ironic problem of librarians becoming impediments to information. Thus, certification supporters advocate updating knowledge, skills, and abilities through certification, lest they become obsolete. In Lynch's (2008) estimation, "As the profession has changed and become more technologically sophisticated,... continuing education programs have been developed, and growing interest in certification programs has emerged" (p. 948). In line with this assessment, Griffiths and King (1986) held that "information professionals must continually update and expand their competencies" (p. 256) to perform effectively in the rapidly changing Information Age. By way of post-graduate certification, certified librarians would effectively affirm that they are competent and knowledgeable to provide high quality information services in the $21^{\text {st }}$ century.

Remedy MLIS deficiencies. Concern over obsolete competencies ties into another justification for certification: the alleged deficiency of the MLIS 
degree. The MLIS draws the ire of continuing education advocates and supporters of certification. Criticism of the MLIS degree is a fashionable topic in the literature (Ingalls \& Sivak, 2005; Swigger, 2010). A recurring thread suggests that the MLIS inadequately prepares librarians for a library service career; rather, critics contend it prepares one for entrance into the profession (Ingalls \& Sivak, 2005, p. 129; Low, 1996, p. 14; Moran, 2003, p. 4). According to Johannah Sherrer (in Low, 1996), "The MLS is relevant if it is regarded as the starting point rather than a capstone of learning. Its value will rest in its ability to concern itself with issues of theory, philosophy of service, history of information... and... technology" (p. 14). Willet (1984) offered a contrary viewpoint, saying, "Some librarians consider the M.L.S. a weak degree because its content is technical rather than academic" (p. 14). Divergent assessments notwithstanding, these arguments lead to the same conclusion: that possessing the MLIS alone is insufficient. Certification is proposed as a cost-effective, practical solution to make up for MLIS deficiencies (Watkins, 1998, p. 11). It is argued that through certification programs, librarians-both novice and seasoned-can augment their competencies with contemporary "industry-specific training" that may not have been available during library school (Ingalls \& Sivak, 2005, pp. 130-132). Thus, certification remedies problems relating to outdated knowledge, skills, and abilities, while encouraging continuing professional development, one of the ALA's Core Competencies of Librarianship. Building upon this notion, Conant (1980) speculated that certification would be mutually beneficial to practitioners and to MLIS programs:

Career education to be effective must be systematic. Periodic certification of librarians tied to a series of formal education requirements would sustain a system of career education. So would certification examinations for selected specialties and responsibilities. Such certification requirements would encourage the development of appropriate courses in library schools and in the professional associations. (pp. 173-174)

In this regard, post-graduate certification ensures high quality service by supplementing and enhancing the "static knowledge" afforded in library school.

Align librarianship with other professions. A third justification is that certification brings librarianship in line with other professions that require practitioners to obtain post-graduate credentials (Carson, 1997; Kraemer, 1948; Williamson, 1923). As explained in the previous section, certification supporters believe that demonstrating high quality service means doing more than completing the initial graduate degree (Burr, 1977; Carson, 1997). According to Martin (1994): 
[T] he mere possession of a degree... does not, in itself, communicate... important values in other professions; why do we assume that librarianship is different, and that we can do with a single degree what other professions must strive for with a formal program of certification and continuing education? (p. 567)

Examples of other professions requiring post-graduate credentials are cited extensively in the literature; they include medicine and nursing (Burr, 1977; Carson, 1997; Lindberg, 1990; Williamson, 1923), law (Burr, 1997; Carson, 1997; Crowley, 2008; Williamson, 1923), accounting (Burr, 1997; Lindberg, 1990; Martin, 1994; Williamson, 1923), and teaching (Kraemer, 1948; Williamson, 1923), to name a few. In all of these examples, the certification/licensure requirements perform the dual role of protecting public welfare and shielding practitioners from liability (Goggin, 1993, p. 187). Aligning librarianship with other professions by way of post-graduate credentialing has two essential benefits. Firstly, it delineates the boundaries of the profession, helping define librarians' roles in terms of service expectations and in relation to paraprofessional personnel (Grady, 2009; Jordan, 1948, pp. 114-115; Lindberg, 1990, p. 157; Williamson, 1923, p. 4). Secondly, it "safeguards" information seekers from unqualified practitioners by requiring librarians to demonstrate that they possess core competencies (Kraemer, 1948, p. 157; Williamson, 1923, p. 124). Possession of post-graduate certification, then, would lead to more reliable information transactions and the provision of higher quality services.

Improve professional status. Librarianship continues to be a misunderstood profession, rife with gender stereotypes and subject to anachronistic misconceptions. Library advocates have strived to improve the public image of librarians through assorted professionalization measures, including certification (Goggin, 1993, p. 189; Lindberg, 1990, p. 157). Professional status enhancement relates closely to the goal of aligning librarianship with other professions: by gaining prestige, librarianship inches closer to disciplines like law and medicine, often described in the literature as "the 'true' professions" (Willet, 1984, p. 19). Image enhancement is not limited to professions whose practitioners possess the "doctor" title, either. According to Carson (1997), "Other professions that have increased their status after instituting licensing and certification include nurses, engineers, accountants, and actuaries" (p. 14).

Certification supporters contend that the benefits of greater prestige apply to individual practitioners and to the larger LIS field. Commenting on 
practitioners, Swigger (2010) said "Certification of individual librarians... is based on the individual's competence... Individual certification... would make librarianship more like the higher-status professions" (p. 146). Jordan (1948) argued that a trickle-down effect would reach the practitioner only after the profession embraced certification:

No certification program of or by itself claims or promises to raise the status, standards, or prestige of a single individual, but it does raise the level of the group and as this level is raised to a professional status, the prestige inherent in any recognized profession cloaks the individual member. (p. 113)

In either conception, supporters say improved status via post-graduate certification will boost librarian salaries, making librarianship a financially attractive profession (Burr, 1977, p. 1729; Jordan, 1948, pp. 112-113; Martin, 1994). In Kraemer's (1948) estimation, "Raising the prestige of the profession and protecting the competent employee are economic reasons for desiring protection by certification laws" (p. 158). Grady (2009, pp. 241-243), Jordan (1948, p. 115) and Goggin (1993, p. 189) agreed that strengthening librarian salaries is a key step to recruiting the best candidates into a library service career. Enhancing the salaries and public image of librarians are measures designed to attract more competitive candidates to LIS careers and to foster greater career satisfaction among practitioners. Both of these objectives are envisaged as ways to elicit higher quality services from librarians.

\section{Arguments Opposing Certification}

Opponents refute the above arguments, saying certification: 1) does not ensure competency; 2) undermines the MLIS; 3) is unfeasible; and 4) does not improve professional status.

No competency assurance. Opponents of certification maintain that postgraduate credentials in the form of either certification or licensure, do not guarantee competency in practitioners (Berg, 1977; Berry, 2001). There is considerable skepticism in the literature over how "competency" for library service is defined and whether a set of pre-determined knowledge, skills, and abilities can accurately measure performance (Robbins-Carter \& Seavey, 1986, p. 570; Thomas et al., 1981, p. 183). Griffiths and King (1986) observed that "it is implied that certification denotes a competent individual. What characterizes competent on-the-job performance is seldom mentioned in connection with 
certification and, to our knowledge, has not been defined" (p. 352). Stripling (2005) agreed and elaborated:

Certification implies quality assurance. To assure quality, one must define the attributes of quality performance and then devise a measurement tool to assess achievement... The attributes for national certification can be described as competencies - what an applicant should know and be able to do.... If it is difficult to identify competencies that are applicable across the country, then it is even more difficult to develop a measurement instrument that is valid, reliable, and equitable. (p. 158)

Just as certification cannot guarantee competency in librarians, it also does not prevent incompetents from practicing (Gross, 1978). This is a matter of probability as much as it is a matter of fact. As Willet (1984) has pointed out, assuming reliable competency testing measures are ever developed, it would be "statistically impossible" for these exams to screen out all incompetents (p. 19). Furthermore, professions with existing certification/licensing requirements-the often-cited fields of law and medicine, for example-still harbor careless, unscrupulous, and incompetent practitioners (Goggin, 1993, p. 189). Today, lawyers still get disbarred, doctors still lose their medical licenses, and so forth. Therefore, the claimed assurance of competency by way of certification or licensing is highly doubtful (Gross, 1978, p. 1014). Gerhardt's (1978) position crystallized this perspective:

[A]ll the talk about "competency-based" requirements does not insure competency on the part of the practitioners. If this were so, then none of the self-certifying occupations or professions would have an incompetent among them - no malpracticing physicians, surgeons, lawyers, or public accountants. So, every time someone urging yet another certification model or licensing procedure for librarians suggests that this activity is for the protection of the public..., it is quite proper to guffaw... (p. 4)

Viewed critically, then, certification supporters are demanding drastic structural changes to librarians' education and training without providing clear justification or evidence for the changes. No consensus has been reached defining "certifiable competencies" or explaining how post-graduate certification ensures high quality services.

Certification undermines the MLIS. U.S. librarian education has had a turbulent history. What began as a career aligned with the clerical trades has in the last century developed into a bona fide profession (Rubin, 2010, pp. 77-126). 
This is largely due to the creation of the MLIS degree. "Most scholars of the sociology of professions agree that professional education is located principally at the graduate level. Librarianship was a leader field on the basis of this criteria," having required the master's degree, in addition to possession of a bachelor's degree, as early as 1951 (Robbins-Carter \& Seavey, 1986, p. 568). Moreover, library degree programs stay relevant because they evolve with the times. For example, as society moved into the Information Age, the graduate library degree updated its curriculum and refined the degree nomenclature (Master of Arts (MA) to Master of Library Science (MLS) to MLIS and Master of Science in Information (MSI)) to reflect the shift towards information and knowledge economies. If MLIS programs stay current by updating their curriculums in response to emerging issues; providing a balanced offering of theory, methods, and practice; adapting to technological changes; and, reaffirming ethics and values, then many consider graduate library programs the best training ground for future librarians (Crowley, 2008; Kavanaugh \& Wescott, 1951, p. 203; Nussbaumer, 2005).

Defenders of the MLIS therefore deride claims that librarian certification would ensure high quality service. If made into the new minimum service qualification, certification would undermine the foundational value of the MLIS by "predispos[ing] a changing profession to a greater degree of relative stagnation" (Griffiths \& King, 1986, p. 358). Considering this possibility led Crowley (2008) to lament that "the MLS, MLIS, or IS master's degrees from ALA-accredited programs will lose their already limited attraction" (p. 10). Rather than ensuring the provision of high quality services, mandatory postgraduate certification could destabilize the meaning, value, and culture of library school education.

Librarianship is too broad to certify. Certification opponents dismiss claims that certification brings librarianship closer to other professions, arguing that library service is a field too broad to certify (Goggin, 1993, p. 189; Griffiths \& King, 1986). Having no "umbrella definition," librarianship means different things in different settings (Gerhardt, 1978, p. 4). Consider the array of subjects librarians deal with and the variety of institutions in which they work, from elementary schools and universities, to museums and archives, to military installations and prisons (Crowley, 2008, pp. 122-125; Ojala, 2003). "Consequently, there is little uniformity upon which to build 'baseline' [postgraduate] credentials for the profession as a whole" (Griffiths \& King, 1986, p. 349). Even if "certifiable competencies" for librarians could be identified, the differences in cultures and norms across the U.S. would make it difficult to apply national certification standards in some local settings (Kavanaugh \& Wescott, 1951, pp. 203-205; Willet, 1984, p. 17). 
The frequent comparison to post-graduate credentialing for lawyers and doctors is dismissed on the grounds that those certification/licensing requirements act as insurance against liabilities inherent in those professions. One's ability to grasp volumes of updated case law and current medical literature and procedures, for example, will reflect directly upon the effectiveness of the legal or medical services provided (Estabrook, 1977, p. 218). In this way, certification and licensing of lawyers and doctors "contribut[e] directly or immediately to [protecting] life or welfare" (Jordan, 1948, p. 111). Drawing a keen distinction, Griffiths and King (1986) observed: "Unlike many other professions, however, the information profession can be said to provide an intangible service that rarely leads to a product or result obvious to the service recipient, let alone a standardized product" (p. 343, emphasis added). It would be dubious to claim that the provision of information is a matter of life and limb (though it might be on rare occasions). Opponents therefore dismiss calls for post-graduate certification and the presumption that it ensures high quality service based on the priorities of the law and medical professions as overwrought hyperbole.

No status/image improvement. Finally, opponents reject the claim that certification enhances status through improvements to salary, career stability, and public image. Berry (2003) doubted certification would serve as effective leverage in hiring and pay considerations (p. 8). That is because salary, employment, promotions, and retention are decisions residing, to a large extent, beyond the jurisdiction of the library profession. As Nussbaumer (2005) explained, "[S]alaries are influenced by the macro- and micro-environment, which are outside the control of certification" (pp. 140-141). "Given the fluctuating financial situation of many libraries, it would be unreasonable to expect certification would give librarians greater job security" (Willet, 1984, pp. 19-20). Mass layoffs of certified teacher-librarians nationwide attest to this sobering fact (Gerhardt, 1978; Tobar, 2011; Willet, 1984, p. 20).

Certification opponents do not refute that the LIS field suffers from a poor public image; they do, however, reject the claim that certification would solve that problem (Berry, 2001; Nussbaumer, 2005). It is hard to understand how certification would improve public perceptions of librarians when the very definition and purpose of librarian certification remain unclear. As Griffiths and King (1986) argued:

When credentials are based upon vague... criteria or are not validly linked to competent on-the-job performance, individuals who receive these credentials run the risk of expending time and effort... to satisfy criteria that may lack relevance to their jobs... The profession in question runs the 
risk of authorizing the credentialed individuals as competent to practice when, in fact, they may not be competent. (pp. 355-356)

The lack of convincing evidence for the need to certify helps neither the practitioner nor the profession. One cannot expect an improved public image by way of certification if the LIS field cannot adequately explain or justify the requirement to begin with. To change public perceptions, Nussbaumer (2005) advised librarians to disregard "credential[s] that will have little, if any, influence on their perceptions" and instead focus on delivering "consistent, client focused, constant and clear" services (p. 142). Objectives such as these, and the general goal of providing the highest quality information services, can be achieved without the benefit of additional "titles" gained through post-graduate certification.

\section{Analysis and Position}

Both sides of the certification debate offer impassioned stances. Supporters and opponents of certification have in mind the best interests of librarians serving as the public face of the LIS profession nationwide, as well as library patrons who seek out their services. Advocacy can be painful, divisive, and sometimes fruitless, so their efforts are to be commended. That said, after examining both sides of this debate, the case for librarian certification is unconvincing. In my assessment, the demands of certification supporters demonstrate their insecurities over librarians' evolving role and a lack of consideration of the expansive bureaucracy that would be created if certification became a condition of professional practice. In the end, arguments for national librarian certification remain unpersuasive because they are based on speculation, not evidence.

Librarianship in the $21^{\text {st }}$ century is more complex than ever before. Librarian education, moreover, has gone through considerable upheaval since the birth of the library science degree. The current trend toward digitization portends continuing evolution and revolution in libraries. Thus, the issue of librarians' ability to deliver high quality service is a paramount concern at this juncture. However, this genuine concern is being exaggerated to the detriment of the LIS field. "It would seem from the literature that librarians struggle excessively to create the outward signs of professional identification" (Robbins-Carter \& Seavey, 1986, p. 561). Such professional insecurity is manifested in the persistent calls for librarian certification. The insecurity is evident in the way certification supporters concern themselves with public perceptions and alignment of librarianship with other professions-conditions which are largely out of their control. Thomas et al. (1981) described these tendencies as "a desperate attempt to validate librarianship as a profession" and "librarians compensat[ing] for their 
inability to demonstrate the value of their skills" (p. 183). Agonizing over the rightful place of librarians within the professional spectrum distracts from the far more important and timely task of finding ways to improve library services in the $21^{\text {st }}$ century. As Nussbaumer (2005) stated, "[I]nstead of writing endless apologetics for our existence, we need to blow our own horns and tell everyone how great we really are. Within this context, I do not see how the process of certification will contribute to the profession" (p. 139).

What is more, certification supporters do not acknowledge the expansive bureaucracy that would be created to support a system of national librarian certification. By virtue of its size and function, the ALA would be the likely organization to develop and administer a post-graduate certification program. As it stands today, ALA membership is entirely voluntary. If certification were to become a nationwide requirement, however, this would compel librarians to join the ALA. Such a requirement could be problematic for several reasons: it entails requisite payment of annual dues and the provision of one's private personal information as a condition of membership; practitioners disagreeing with ALA policies and positions may have to sacrifice their principles in the interest of career survival; and it creates yet another bureaucracy for practitioners, employers, and the public to navigate. This last point warrants elaboration.

Librarian certification or licensing would be trivial without the backing of some regulatory authority. Passage of certification/licensing requirements would very likely set in motion several public and private processes toward that end. As Crowley (2008) described, "[L]aws will be passed by legislatures to create new certification approaches... Afterward, new... regulations will be issued, with the period of time for public comment, by state library agencies to implement new... certification requirements for professional librarians" (p. 9). The resulting certification process would likely entail an exam, perhaps supplemented by interviews, a portfolio, and maintenance of continuing education credits. All of this comes with requisite costs in terms of time, effort, and money. Freeman (1994) identified two significant "logistical and bureaucratic" problems if this process is implemented: the ALA would have to ensure equitable access to the examination in terms of cost and testing locations; and the ALA, now serving in a gate-keeper function, would have to "police" the certified cadre and perhaps even take disciplinary measures against practitioners who violate professional standards (p. 28). This last function significantly expands the ALA's power. In Berg's (1977) view, this new arrangement results in a tenuous "dependency relationship" between librarians and the ALA, adding, "The history of regulatory procedures in many jurisdictions and on many issues, both nationally and statewide, suggests that regulation generates at least as many problems as it solves" (p. 90). 
This problematic regulatory aspect has not dissuaded certification supporters. On the contrary, they have continued to advance the certification cause despite the fact that the data are not in their favor. The certainty with which supporters of certification demand its implementation belies the absence of "compelling evidence" to support their stance (Berry, 2001, p. 96). Early on in the debate, Tai (1925) observed: "Whether the national certification system of librarianship will be useful or not depends upon certain objective measurements scientifically valid and reliable. So far the arguments for [certification] are chiefly emotional and subjective in nature" (p. 130). Arguing for certification, Kraemer (1948) nevertheless admitted that "most of the material published on the subject of certification has been an expression of opinion rather than a factual study" (p. 169). She recommended comparative studies of certified and noncertified librarians to assess competence (Kraemer, 1948, p. 169). While these studies were never undertaken, other studies conducted since then have not found certification necessary. In an early study by Kavanaugh and Westcott (1951), there was consensus among the librarians surveyed in favor of university-based library school education rather than certification. Boaz's (1978) study querying library school deans and faculty about future trends found that less than half of the respondents thought mandatory certification was "probable;" the need for certification fell between "neutral" and "desirable" (pp. 318-319). According to Nussbaumer (2005), a study of the archival field "found little correlation between certification and salary scales" (p. 140). The absence of compelling evidence justifying national librarian certification cannot be disregarded.

In light of these findings, and after a careful review of the literature, it becomes apparent that arguments for national librarian certification remain unconvincing. Librarian certification is a cause célèbre advanced without the benefit of evidence or corroborative data. While they may have good intentions, certification supporters offer essentially conjecture and aspiration. These are insufficient grounds to fundamentally alter the education and training of librarians.

\section{Conclusion}

This paper examined whether certification of librarians is necessary to ensure high quality service. The paper reviewed the purpose of certification in other professions, the history of librarian certification initiatives in the U.S., and the arguments supporting and opposing national librarian certification. Upon reviewing the literature, I concluded that certification supporters: 1) evince an underlying insecurity about the librarian's evolving role, 2) fail to consider the expansive bureaucracy certification would create, and 3) offer no evidentiary 
basis to support certification. Based on this critical assessment, I concluded that librarian certification is not necessary to ensure high quality service.

Though the case for certification is unconvincing, I do acknowledge that improving service delivery, encouraging professional development, and enhancing librarians' salaries are important objectives. However, I interpret these as means to a greater end; that of enhancing the librarian's role, importance, and impact in the $21^{\text {st }}$ century. Let us not pin our hopes on an additional "title" to achieve this end. Instead, librarians should consider taking other proactive steps; for example, getting out from behind the reference desk to effect the change they want to see. Librarians must establish stronger relationships with library schools, alumni, and the ever-widening array of institutions that employ librarians, in order to communicate to library educators the competencies future librarians must possess. Librarians must take advantage of new technologies to market library services to a wider audience, especially to underserved populations. Librarians, when away from the reference desk, must drop the safe harbor of "professional objectivity" and become more politically active. Finally, librarians must lobby local, state, and federal leaders for increased library support, and remind them that libraries, librarians, and paraprofessional personnel contribute greatly to the civic, cultural, and educational well-being of the community.

\section{References}

Academy of Certified Archivists. (2012). The academy of certified archivists. Retrieved from http://www.certifiedarchivists.org/

American Library Association. (2009). Core competencies of librarianship. Retrieved from http://www.ala.org/ala/educationcareers/ careers/corecomp/corecompetences/finalcorecompstat09.pdf

American Library Association. (2012). Office of accreditation. Retrieved from http://www.ala.org/offices/accreditation

American Library Association-Allied Professional Association. (2012). Library support staff certification. Retrieved from http://ala-apa.org/lssc/aboutlssc/

American Planning Association. (2012). American Institute of Certified Planners $(A I C P)$. Retrieved from http://www.planning.org/certification/ 
American Society for Industrial Security. (2012). American Society for Industrial Security (ASIS) board certifications in security. Retrieved from $\mathrm{http} / / / \mathrm{www}$.asisonline.org/certification/index.xml

Berelson, B. (1949). Education for librarianship: Papers presented at the library conference, University of Chicago, August 16-21, 1948. Chicago, IL: American Library Association.

Berg, I. (1977). The licensing of paraprofessionals. In L. S. Estabrook (Ed.), Libraries in post-industrial society (pp. 85-93). Phoenix, AZ: Oryx Press.

Berry, J. N. (2001). Certification: Is it worth the price? Library Journal, 126(3), 96.

Berry, J. N. (2003). Is certification the answer? Library Journal, 128(1), 8.

Boaz, M. (1978). The future of library and information science education. Journal of Education for Librarianship, 18(4), 315-323.

Bontenbal, K. (2010). History of libraries: Ancient libraries. San Jose State University [Lecture]. San Jose, CA. Retrieved from http://slisweb.sjsu.edu/d2l.

Brumley, R. (2007). Certifiable success. Library Journal, 132(3), 46.

Burr, R. L. (1977). Certification and competence. Library Journal, 102(15), 17281729.

Carroll, C. E. (1970). The professionalization of education for librarianship, with special reference to the years 1940-1960. Metuchen, NJ: Scarecrow Press.

Carson, B. M. (1997). Librarians need licensing and certification. AALL Spectrum, 1(9) 13-15. Retrieved from http://people.wku. edu/bryan.carson/articles/certlic.htm

Certified Financial Planner. (2012). Certified Financial Planner (CFP) Board of Standards Inc. Retrieved from http://www.cfp.net/

Conant, R. W. (1980). The Conant report: A study of the education of librarians. Cambridge, MA: MIT Press. 
Crowley, B. (2008). Renewing professional librarianship: A fundamental rethinking. Westport, CT: Libraries Unlimited.

Equating Professional Library Qualifications. (1960). Journal of Education for Librarianship, 1(1), 22-32.

Estabrook, L. S. (Ed.). (1977). Libraries in post-industrial society. Phoenix, AZ: Oryx Press.

Freeman, M. (1994). A sense of direction: Librarianship and CPD. Librarian Career Development, 2(3), 26-28.

Gerhardt, L. N. (1978). Certification revisited. School Library Journal, 24(17), 4.

Goggin, M. K. (1993). Certification of librarians. In World encyclopedia of library and information services ( $3^{\text {rd }}$ ed.) (pp. 186-189). Chicago, IL: American Library Association.

Grady, J. (2005). National librarian certification. Interface, 27(4). Retrieved from http://www.ala.org/ala//mgrps/divs/ascla/asclapubs/interface/ archives/contentlistingby/volume27/nationallibrariancertification /certification.cfm

Grady, J. (2009). Answering the calls of "what's next" and "library workers cannot live by love alone" through certification and salary research. Library Trends, 58(2), 229-245.

Griffiths, J. M., \& King, D. W. (1986). New directions in library and information science education. White Plains, NY: Knowledge Industry Publications.

Gross, S. J. (1978). The myth of professional licensing. American Psychologist, 33(11), 1009-1016.

Gustaitis, J. (1986, April). Melvil Dewey: He was one for the books. American History Illustrated, 38-39.

Ingalls, E., \& Sivak, A. (2005). Post-master's certification: A case for responsive education. In S. E. Cleyle \& L. M. McGillis (Eds.), Last one out turn off the lights: Is this the future of American and Canadian libraries? (pp. 125-137). Lanham, MD: Scarecrow Press. 
Institute of Certified Records Managers. (2012). Retrieved from http://www.icrm.org/

International Information Systems Security Certification Consortium. (2012). International Information Systems Security Certification Consortium (ISC2) Certification Programs. Retrieved from https://www.isc2.org/credentials/default.aspx

Jesseman, D. J., Page, S. M., \& Underwood, L. (2011). School library media certification by state. School Library Monthly. Retrieved from http://www.schoollibrarymonthly.com/cert/index.html

Jordan, M. (1948). Certification: A stage of professionalization. Bulletin of the Medical Library Association, 36(2), 108-116.

Kaatrude, P. B. (1992). Librarian certification and licensing: A brief accounting. Public Libraries, 31(3), 155-157.

Kavanaugh, I. M., \& Wescott, E. C. (1951). A national examination as a basis for library certification: A survey of opinion. Library Quarterly, 21(3), 198205.

Kraemer, R. (1948). Certification of librarians: Implications drawn from the field of teaching. Library Quarterly, 18(3), 157-170.

Library Journal. (1921). Library Journal, 46(1), 856.

Lindberg, C. H. (1990). Certification, status, and salaries. Journal of Education for Library and Information Science, 31(2), 157-161.

Low, K. (Ed.). (1996). The roles of reference librarians: Today and tomorrow. New York, NY: Haworth Press.

Lynch, B. P. (2008). Library education: Its past, its present, its future. Library Trends, 56(4), 931-953.

Martin, S. K. (1994). Librarianship and certification. College \& Research Libraries News, 55(9), 567.

Medical Library Association. (2012). Academy of Health Information 
Professionals. Retrieved from http://www.mlanet.org/academy/

Moran, R. F. (2003). ALA/APA post-master's certification: An interview with Tom Wilding. Library Administration and Management, 17(1), 4-5.

Nussbaumer, A. (2005). Door \#1: certification. Door \#2: not! Door \#3: real solutions. In S. E. Cleyle \& L. M. McGillis (Eds.), Last one out turn off the lights: Is this the future of American and Canadian libraries? (pp. 138-150). Lanham, MD: Scarecrow Press.

Ojala, M. (2003). Certifying information professionals. Online, 27(2), 5.

Phillips, J. (2004). Professional certification: Does it matter? Information Management Journal, 38(6), 64-67.

Robbins-Carter, J., \& Seavey, C. A. (1986). The master's degree: Basic preparation for professional practice. Library Trends, 34(4), 561-580.

Rubin, R. E. (2010). Foundations of library and information science ( $3^{\text {rd }}$ ed.). New York, NY: Neal-Schuman.

Sherrer, J. (1996). Thriving in changing times: Competencies for today's reference librarians. In K. Low (Ed.), The roles of reference librarians: Today and tomorrow (pp. 11-18). New York, NY: Haworth Press.

Stripling, B. K. (2005). The certification debate: Will you, won't you, will you, won't you, will you join the dance? In S. E. Cleyle \& L. M. McGillis (Eds.), Last one out turn off the lights: Is this the future of American and Canadian libraries? (pp. 151-162). Lanham, MD: Scarecrow Press.

Swigger, B. K. (2010). The MLS project: An assessment after sixty years. Lantham, MD: Scarecrow Press.

Tai, T. C. (1925). Professional education for librarianship. New York, NY: H. W. Wilson.

Thomas, D. M, Hinckley, A. T., \& Eisenbach, E. R. (1981). The effective reference librarian. New York, NY: Academic Press.

Tobar, H. (2011, May 13). Disgraceful interrogations; LAUSD forces librarians to prove they should stay on payroll. Los Angeles Times, p. A2. 
Watkins, C. (1998). Chapter report: The many faces of certification. American Libraries, 29(9), 11.

White, C. M. (1976). A historical introduction to library education: Problems and progress to 1951. Metuchen, NJ: Scarecrow Press.

Willet, H. G. (1984). Certification and education for library and information science. Journal of Education for Library and Information Science, 25(1), 13-23.

Williamson, C. C. (1923). Training for library service: A report prepared for the Carnegie Corporation of New York. New York, NY: Updike. 